\title{
Predictors of intubation and mortality in COVID-19 patients: a retrospective study
}

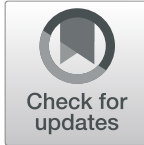

Tiziana Cena ${ }^{1 * \dagger}$, Gianmaria Cammarota ${ }^{1 \dagger}$, Danila Azzolina ${ }^{2}$, Michela Barini $^{3}$, Simona Bazzano ${ }^{1}$, Domenico Zagaria ${ }^{3}$, Davide Negroni ${ }^{3}$, Luigi Castello ${ }^{4}$, Alessandro Carriero ${ }^{2,3}$, Francesco Della Corte $^{1,2}$ and Rosanna Vaschetto ${ }^{1,2}$

\begin{abstract}
Background: Estimating the risk of intubation and mortality among COVID-19 patients can help clinicians triage these patients and allocate resources more efficiently. Thus, here we sought to identify the risk factors associated with intubation and intra-hospital mortality in a cohort of COVID-19 patients hospitalized due to hypoxemic acute respiratory failure (ARF).
\end{abstract}

Results: We included retrospectively a total of 187 patients admitted to the subintensive and intensive care units of the University Hospital "Maggiore della Carità" of Novara between March 1st and April 30th, 2020. Based on these patients' demographic characteristics, early clinical and laboratory variables, and quantitative chest computerized tomography (CT) findings, we developed two random forest (RF) models able to predict intubation and intra-hospital mortality. Variables independently associated with intubation were C-reactive protein $(p<0.001)$, lactate dehydrogenase level $(p=0.018)$ and white blood cell count $(p=0.026)$, while variables independently associated with mortality were age $(p<0.001)$, other cardiovascular diseases $(p=0.029)$, C-reactive protein $(p=0.002)$, lactate dehydrogenase level $(p=0.018)$, and invasive mechanical ventilation $(p=0.001)$. On quantitative chest $C T$ analysis, ground glass opacity, consolidation, and fibrosis resulted significantly associated with patient intubation and mortality. The major predictors for both models were the ratio between partial pressure of arterial oxygen and fraction of inspired oxygen, age, lactate dehydrogenase, C-reactive protein, glycemia, $\subset T$ quantitative parameters, lymphocyte count, and symptom onset.

Conclusions: Altogether, our findings confirm previously reported demographic, clinical, hemato-chemical, and radiologic predictors of adverse outcome among COVID-19-associated hypoxemic ARF patients. The two newly developed RF models herein described show an overall good level of accuracy in predicting intra-hospital mortality and intubation in our study population. Thus, their future development and implementation may help not only identify patients at higher risk of deterioration more effectively but also rebalance the disproportion between resources and demand.

Keywords: COVID-19, Intubation, Factor risk, Mortality, Quantitative computerized tomography, Random forest

\section{Introduction}

Severe acute respiratory syndrome coronavirus 2 (SARSCoV-2) causes a wide spectrum of clinical manifestations, named coronavirus disease 19 (COVID-19), which range from asymptomatic infections to severe interstitial pneumonia. Unfortunately, the COVID-19 pandemic has

\footnotetext{
* Correspondence: titti.cena@gmail.com

†Tiziana Cena and Gianmaria Cammarota contributed equally to this work. ${ }^{1}$ Anestesia e Terapia Intensiva, Azienda Ospedaliero Universitaria "Maggiore della Carità", Novara, Italy

Full list of author information is available at the end of the article
}

led to a large number of critically ill patients in a very short time and is currently overwhelming the healthcare systems worldwide [1].

In this scenario, delays in intensive care unit (ICU) transfers [2-4] and in patient intubations [5, 6] have been associated with increased mortality among COVID-19 patients with hypoxemic acute respiratory failure (ARF). Thus, correct triage and prompt ICU allocation of patients scheduled to receive intubation in case of oxygen therapy or noninvasive ventilation failure are

(c) The Author(s). 2021 Open Access This article is licensed under a Creative Commons Attribution 4.0 International License, which permits use, sharing, adaptation, distribution and reproduction in any medium or format, as long as you give appropriate credit to the original author(s) and the source, provide a link to the Creative Commons licence, and indicate if changes were made. The images or other third party material in this article are included in the article's Creative Commons licence, unless indicated otherwise in a credit line to the material. If material is not included in the article's Creative Commons licence and your intended use is not permitted by statutory regulation or exceeds the permitted use, you will need to obtain permission directly from the copyright holder. To view a copy of this licence, visit http://creativecommons.org/licenses/by/4.0/. 
crucial to achieve an effective COVID-19 pandemic response [7].

Potential prognostic factors of intra-hospital mortality and intubation in patients hospitalized due to COVID-19related hypoxemic ARF include older age [8, 9], male gender [9], diabetes [9], prothrombin time and D-dimer level [10], lymphocytopenia [11-13], leukopenia [11-13], Creactive protein [11-13], lactate dehydrogenase [11-13], sequential organ failure assessment (SOFA) score [14], arterial oxygen pressure on inspired oxygen fraction ratio $\left(\mathrm{PaO}_{2} / \mathrm{FiO}_{2}\right)[8,14]$, and acute kidney injury [14].

The Fleischner Society Statement on Chest Imaging and COVID-19-issued on April 7th, 2020-recommends chest computerized tomography (CT) imaging for the triage of $(i)$ patients with suspected COVID-19 presenting with moderate to severe clinical features and a high pretest probability of disease, (ii) COVID-19 patients with worsening respiratory status, and (iii) patients with functional impairment and/or hypoxemia after recovery from COVID-19 [15, 16]. Fittingly, a singlecenter study has recently shown how the compromised lung volume estimated by quantitative $\mathrm{CT}$ analysis is a strong predictor of the need for oxygenation support and intubation among COVID-19 patients [17]. Thus, an algorithm combining demographic and early clinical characteristics together with laboratory findings and chest CT analysis results may favor the early identification of COVID-19 patients requiring invasive mechanical ventilation (IMV) or at increased risk of mortality.

Our primary aim was to retrospectively identify the risk factors associated with intubation and intra-hospital mortality in a cohort of COVID-19 patients admitted to the hospital for hypoxemic ARF by analyzing their demographic characteristics, early clinical and laboratory variables, and quantitative chest $\mathrm{CT}$ analysis results. As a secondary endpoint, we sought to determine the performance of a newly developed algorithm based on the aforementioned variables in predicting the probability of IMV and intra-hospital mortality in our study population.

\section{Methods}

\section{Patients and data}

The present investigation is an observational retrospective single-center study. Ethical approval was issued by the Comitato Etico Interaziendale Novara, Italy (Chairperson Prof. G. Zulian) on May 20th, 2020 (Ethics Committee No. CE 121/20). The requirement for informed consent was waived due to the retrospective nature of the study.

We analyzed 187 consecutive patients with COVID-19 pneumonia diagnosed with real-time reverse transcriptase-polymerase chain reaction (RT-PCR) nasopharyngeal swabs, subjected to chest $\mathrm{CT}$ images, and admitted to the subintensive and intensive care units of our hospital between March 1st and April 30th, 2020. Patients with poor-quality chest CT images were excluded. The study was reported in accordance with STROBE guidelines.

\section{Clinical and laboratory characteristics}

Demographic information, body mass index (BMI), time from first-symptoms, comorbidity, date of admission to hospital, clinical laboratory on admission including the first $\mathrm{PaO}_{2} / \mathrm{FiO}_{2}$ ratio, arterial oxygen saturation $\left(\mathrm{SpO}_{2}\right)$, blood cell counts (i.e., leukocyte and lymphocyte count), biomarkers of inflammation (i.e., lactate dehydrogenase, ferritin, C-reactive protein, procalcitonin, fibrinogen), glycemia, and troponin were collected. Furthermore, we recorded the type of oxygen assistance administeredi.e., standard oxygen therapy (low-flow oxygen nasal cannula, Venturi mask, non-rebreathing mask), noninvasive ventilation [continuous positive airway pressure (CPAP) or bilevel positive airway pressure (BiPAP)], or invasive mechanical ventilation. All data were derived from both electronic hospital records and digitization of paper documents.

\section{Criteria for intubation}

Criteria for intubation were cardiac or respiratory arrest; inability to protect the airway; coma or psychomotor agitation; unmanageable secretions or uncontrolled vomiting; life-threatening arrhythmias or electrocardiographic signs of ischemia; hemodynamic instability, defined as systolic arterial pressure $<90 \mathrm{mmHg}$ despite adequate filling or use of vasoactive agents; intolerance to all interfaces; dyspnea during noninvasive ventilation administered as CPAP or BiPAP; respiratory rate $>30$ breaths/ min; $\mathrm{SpO}_{2}<92 \%$ during CPAP or BiPAP; and acidosis.

\section{Quantitative CT analysis}

CT scan was performed within 1 day from admission. CT images were independently reviewed by two radiologists with 10 and 14 years of clinical experience: all radiologists were blinded to the clinical status of the patients. The lung parenchyma segmentation was performed through a software-based evaluation on a dedicated workstation using the open-source 3D Slicer software (Fig. 1). More details can be found in the Supplementary Information.

\section{Statistical analysis}

A sample size was computed to ensure a predictive ability of the RF model close to 0.8 with a margin of error in the sample estimates $d=0.05$. More details can be found in the Supplementary Information. Descriptive statistics were reported as median and interquartile range for continuous variables and percentages (absolute 


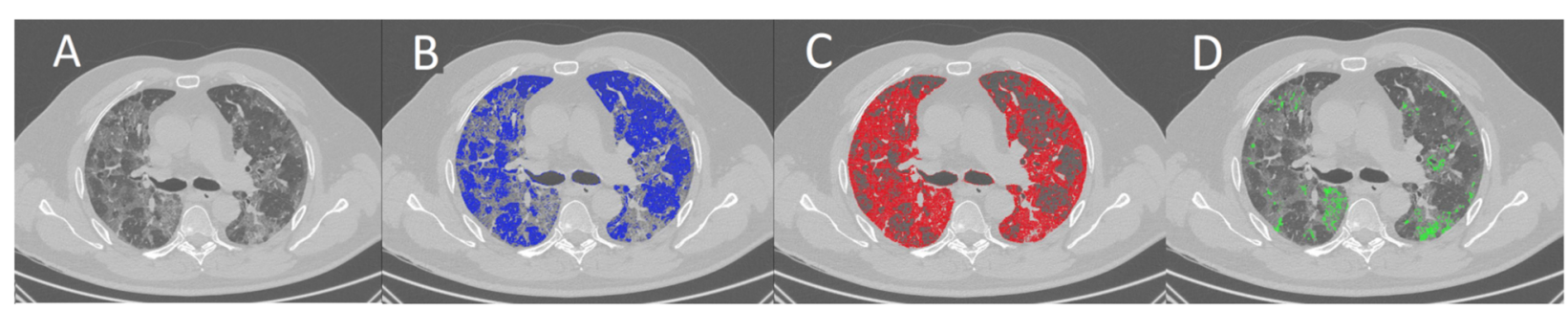

Fig. 1 Quantitative CT analysis of a 74-year-old male COVID-19 patient. a Non-contrast chest CT on admission, showing a characteristic bilateral and subpleural ground glass opacity (GGO). b Well-aerated parenchyma segmented semi-automatically by a 3D slicer; the blue area is the result of the subtraction of the all parenchyma ( $\mathrm{HU}-1100 ;-250)$ with GGO $(-700 ;-250)+$ consolidation $(-250 ;+150)$. c The GGO area, obtained by semi-automatic segmentation ( $\mathrm{HU}-700 ;-250)$. d Manual segmentation of consolidation areas $(\mathrm{HU}-250 ;+150)$

numbers) for categorical variables. Missing values were handled leaving null the estimate. The logistic regression model, odds ratio (OR) together with the 95\% confidence intervals $(95 \% \mathrm{CI})$, and $p$ values were reported for each predictor, considering separately their association with intubation and intra-hospital mortality. The analyses were performed using $\mathrm{R}$ software (version 0.2 ) with the packages caret and rms.

\section{Random forest predictive tool Model}

To identify predictors of intra-hospital intubation or mortality, a random forest (RF) algorithm was employed. The variables having less than $10 \%$ of missing values were included in the predictive tool. More details can be found in the Supplementary Information.

\section{Results}

\section{Patient characteristics}

The main characteristics of the 187 patients included in the study are summarized in Table 1 . One hundred forty patients $(\sim 75 \%)$ were males, with a median age of 64 years, a median BMI of $28 \mathrm{~kg} / \mathrm{m}^{2}$, and a median $\mathrm{PaO}_{2} /$ $\mathrm{FiO}_{2}$ of $258 \mathrm{mmHg}$ on admission. The median symptom onset was 7 days prior to admission. The most frequent comorbidities were hypertension (51\%) and diabetes (24\%). Main laboratory and chest CT findings on admission are also reported in Table 1. Forty-five patients (24\%) received standard oxygen therapy, 86 patients (46\%) received noninvasive ventilation, and 56 patients (30\%) were admitted to ICU and required IMV.

\section{Risk factors}

The patients' demographic, clinical, and laboratory characteristics along with chest $\mathrm{CT}$ analysis findings relative to both the whole study population and alive $v s$ death subjects are listed in Table 1 . When stratifying patients according to mortality, variables independently associated with mortality were age, other cardiovascular diseases except for coronary artery disease, C-reactive protein, lactate dehydrogenase levels, and IMV.
Furthermore, on quantitative chest CT examination, we found a significant positive association between GGO and consolidation and fibrosis. Conversely, female sex, $\mathrm{PaO}_{2} / \mathrm{FiO}_{2}, \mathrm{SpO}_{2}$, lymphocytes count, standard oxygen therapy, and evidence of well-aerated lung parenchyma on chest CT scan were all inversely associated with mortality.

Table 2 enlists the patients' demographic, clinical, and laboratory characteristics along with the chest CT analysis findings relative to both the whole population and intubated $v s$ non-intubated patients. Among our cohort of 187 patients, 29 patients were excluded from this analysis because classified as "do-not-intubate" subjects, i.e., patients deemed ineligible for intubation in case of CPAP or BiPAP failure. Variables independently associated with intubation were C-reactive protein, lactate dehydrogenase levels, and white blood cell count. On quantitative chest CT analysis, GGO, consolidation, and fibrosis resulted positively associated with intubation, while $\mathrm{PaO}_{2} / \mathrm{FiO}_{2}, \mathrm{SpO}_{2}$, lymphocyte count, and wellaerated parenchyma were inversely associated with intubation. Lastly, for each logistic regression and for the continuous variables the cut points maximizing the best predictive value along with their corresponding area under the curve (AUC) are shown in Tables 1 and 2.

\section{RF algorithm}

We next evaluated the importance of the variables encompassed in the RF algorithms for intra-hospital mortality and intubation prediction. In the RF model for mortality prediction, the most important nodes (importance $>50$ ) were $\mathrm{C}$-reactive protein, age, $\mathrm{PaO}_{2} / \mathrm{FiO}_{2}$, glycemia, $\mathrm{SpO}_{2}$ on admission, a well-aerated parenchyma, lactate dehydrogenase, GGO, lymphocytes, other consolidation/fibrosis, and symptom onset (Fig. 2A). In the $\mathrm{RF}$ tree model for intubation prediction, the most important nodes (importance $>50$ ) were $\mathrm{PaO}_{2} / \mathrm{FiO}_{2}$, a well-aerated parenchyma, C-reactive protein, GGO, other consolidation/fibrosis, glycemia, lactate dehydrogenase, lymphocytes, and age (Fig. 2B). The variables having more than $10 \%$ of missing values were excluded 
Table 1 Patient characteristics and clinical, laboratory, and CT findings relative to alive and death patients

\begin{tabular}{|c|c|c|c|c|c|c|c|}
\hline Variable & Valid cases & $\begin{array}{l}\text { Alive } \\
n=129\end{array}$ & $\begin{array}{l}\text { Death } \\
n=58\end{array}$ & Total & OR (univariable) & Cut point & AUC \\
\hline Age (year) & & $62(55-69)$ & $71(63-78)^{*}$ & $64(57-72)$ & $2.42(1.54-3.97, p<0.001)$ & 65 & 0.69 \\
\hline \multicolumn{8}{|l|}{ Sex } \\
\hline Male & 140 & 90 (70\%) & $50(86 \%)$ & 140 (75\%) & - & - & \\
\hline Female & 47 & 39 (30\%) & $8(14 \%)^{*}$ & $47(25 \%)$ & $0.37(0.15-0.82, p=0.019)$ & - & \\
\hline $\mathrm{PaO}_{2} / \mathrm{FIO}_{2}$ ratio & 181 & $267(227-306)$ & $217(168-266)^{*}$ & $258(208-309)$ & $0.48(0.30-0.75, p=0.002)$ & 241 & 0.68 \\
\hline $\mathrm{SpO}_{2}(\%)$ & 187 & $92(89-95)$ & $87(80-93)^{*}$ & 91 (87-95) & $0.63(0.47-0.84, p=0.002)$ & 88.4 & 0.66 \\
\hline Symptom onset & 177 & $7(5-10)$ & $7(4-9)$ & $7(5-10)$ & $0.71(0.43-1.13, p=0.160$ & 1 & 0.58 \\
\hline Body mass index $\left(\mathrm{kg} / \mathrm{m}^{2}\right)$ & 129 & $27.7(24-31)$ & $27.3(24-31)$ & $27.5(24-31)$ & $0.73(0.47-1.09, p=0.143)$ & 27.77 & 0.55 \\
\hline \multicolumn{8}{|l|}{ Comorbidity } \\
\hline Hypertension & 187 & $60(47 \%)$ & $36(62 \%)^{*}$ & 96 (51\%) & $1.88(1.01-3.58, p=0.050)$ & - & - \\
\hline$C A D$ & 187 & $10(8 \%)$ & $10(17 \%)$ & $20(11 \%)$ & $2.48(0.96-6.42, p=0.058)$ & - & - \\
\hline Other cardiovascular disease & 187 & $7(5 \%)$ & $9(15 \%)^{*}$ & $16(9 \%)$ & $3.20(1.13-9.42, p=0.029)$ & - & - \\
\hline Neurologic & 187 & $6(5 \%)$ & $3(5 \%)$ & $9(5 \%)$ & $1.12(0.23-4.40, p=0.878)$ & - & - \\
\hline Diabetes & 187 & $29(23 \%)$ & $16(28 \%)$ & $45(24 \%)$ & $1.31(0.64-2.65, p=0.451)$ & - & - \\
\hline Chronic kidney failure & 187 & $8(6 \%)$ & $6(10 \%)$ & $14(8 \%)$ & $1.75(0.55-5.27, p=0.324)$ & - & - \\
\hline Oncologic & 187 & $9(7.0 \%)$ & $9(16 \%)$ & $18(10 \%)$ & $2.45(0.91-6.63, p=0.074)$ & - & - \\
\hline Dyslipidemia & 187 & $18(14.0 \%)$ & $8(14 \%)$ & $26(14 \%)$ & $0.99(0.38-2.35, p=0.977)$ & - & - \\
\hline COPD & 187 & $5(4 \%)$ & $5(9 \%)$ & $10(5 \%)$ & $2.34(0.63-8.74, p=0.193)$ & - & - \\
\hline Asthma & 187 & $3(2 \%)$ & $2(3 \%)$ & $5(3 \%)$ & $1.50(0.19-9.29, p=0.662)$ & - & - \\
\hline Autoimmune disease & 187 & $11(9 \%)$ & $4(7 \%)$ & $15(8.0 \%)$ & $0.79(0.21-2.44, p=0.705)$ & - & - \\
\hline Mental illness & 187 & $6(5 \%)$ & $3(5 \%)$ & $9(5 \%)$ & $1.12(0.23-4.40, p=0.878)$ & - & - \\
\hline \multicolumn{8}{|l|}{ Smoking history } \\
\hline Never & 172 & $121(94 \%)$ & $51(88 \%)$ & $172(92.0 \%)$ & & - & - \\
\hline Current or former & 15 & $8(6 \%)$ & $7(12 \%)$ & $15(8.0 \%)$ & $2.08(0.69-6.08, p=0.179)$ & - & - \\
\hline \multicolumn{8}{|l|}{$\mathrm{CT}$ findings } \\
\hline Well-aerated Parenchyma & 187 & $72(63-81)$ & $62(50-75)^{*}$ & $68(57-79)$ & $0.51(0.33-0.77, p=0.002)$ & 66.1 & 0.65 \\
\hline Ground glass opacity & 187 & $24(15-33)$ & $32(24-41)^{*}$ & $26(16-35)$ & $1.95(1.24-3.14, p=0.005)$ & 29 & 0.64 \\
\hline Other: consolidation and fibrosis & 187 & $3(0.3-5)$ & $6(0.7-10)^{*}$ & $3(0.2-7)$ & $1.47(1.08-2.04, p=0.017)$ & 5.7 & 0.62 \\
\hline \multicolumn{8}{|l|}{ Laboratory findings } \\
\hline White blood count, $\times 10^{3} / \mu \mathrm{L}$ & 187 & $6.1(4.2-7.9)$ & $6.9(4.8-9)$ & $6.2(4.2-8.2)$ & $1.20(0.87-1.67, p=0.259)$ & 6.96 & 0.55 \\
\hline Lymphocytes count, $\times 10^{3} / \mu \mathrm{L}$ & 187 & $1(0.7-1.3)$ & $0.8(0.5-1)^{*}$ & $1(0.7-1.3)$ & $0.64(0.40-0.96, p=0.047)$ & 1 & 0.6 \\
\hline C-reactive protein, mg/dL & 186 & $8(2-13)$ & $11(5-16)^{*}$ & $8(3-14)$ & $2.15(1.34-3.53, p=0.002)$ & 8.42 & 0.65 \\
\hline Lactate dehydrogenase, U/L & 149 & $708(505-911)$ & $824(601-1047)^{*}$ & $754(543-965)$ & $1.70(1.10-2.69, p=0.018)$ & 786 & 0.62 \\
\hline Glycemia, mg/dL & 187 & $120(97-143)$ & $133(108-157)$ & $125(101-149)$ & $1.22(0.97-1.54, p=0.086)$ & 138 & 0.59 \\
\hline Fibrinogen, mg/dL & 70 & $576(506-647)$ & 591 (489-693) & $580(502-658)$ & $1.25(0.83-1.92, p=0.280)$ & 597 & 0.53 \\
\hline Ferritin, ng/mL & 57 & $1041(588-1494)$ & $1300(872-1728)$ & $1125(671-1579)$ & $1.53(1.01-2.56, p=0.068)$ & 1139 & 0.67 \\
\hline Procalcitonin & 118 & $0.1(0.05-0.1)$ & $0.3(0.05-0.5)$ & $0.1(0-0.2)$ & $1.05(1.00-1.12, p=0.120)$ & 0.23 & 0.76 \\
\hline Troponine ng/L & 109 & $11(3-19)$ & $17(4-30)$ & $12(2-22)$ & $1.00(0.94-1.05, p=0.913)$ & 22 & 0.65 \\
\hline \multicolumn{8}{|l|}{ Oxygenation support } \\
\hline Standard $\mathrm{O}_{2}$ therapy & & $41(32 \%)$ & $4(7 \%)^{*}$ & & $0.27(0.07-0.76, p=0.022)$ & & \\
\hline Non invasive ventilation & & $63(49 \%)$ & $23(40 \%)$ & & - & & \\
\hline Intubated & & $25(19 \%)$ & $31(53 \%)^{*}$ & & $3.40(1.68-7.00, p=0.001)$ & & \\
\hline
\end{tabular}

Descriptive statistics were reported as median and interquartile range for continuous variables and percentages (absolute numbers) for categorical variables. The logistic regression model, Odds Ratio (OR) together with the $95 \%$ confidence intervals $(95 \% \mathrm{Cl})$, and $p$ values are reported for each predictor considered. Asterisks show statistical significance variables. The cut point maximizing the sum of sensitivity and specificity is shown for the continuous variable together with the corresponding area under the curve (AUC) 
from the predictive tool (i.e., BMI, fibrinogen, procalcitonin, ferritin, and troponin). The balanced accuracy in predicting intra-hospital mortality was 0.89 ( $\kappa$ value $=$ 0.72 ; AUC $=0.73)($ Fig. 3A), whereas the balanced accuracy in predicting intubation was $0.9(\kappa$ value $=0.75$; AUC $=0.74)($ Fig. $3 \mathrm{~B})$. When the quantitative CT analysis variables were removed from both RF models, the accuracy of the model predicting intra-hospital mortality dropped to 0.75 , whereas that of the model predicting intubation fell to 0.69 (Fig. 4A, B).

\section{Discussion}

The main findings of our investigation can be summarized as follows: ( $i$ ) in our cohort of COVID-19 patients, elderly male subjects with comorbidities, such as other cardiovascular diseases, intubated for severe hypoxemic ARF associated with a major inflammatory response and a widespread pulmonary involvement on chest $\mathrm{CT}$ were at increased risk of intra-hospital mortality; (ii) excluding those patients classified as "do-not-intubate," subjects with severe hypoxemic ARF experiencing increased inflammatory response and poor lung aeration on chest CT were at increased risk of intubation; and (iii) our novel RF algorithms performed well in predicting intrahospital mortality and intubation in our study population.

The intra-hospital mortality rate of critically ill patients admitted for COVID-19 has been reported to range from 17 to $67 \%$ [18]. Well recognized risk factors associated with low survival or poor outcome in ICU are: male gender, increasing age, comorbidities such as diabetes, hypercholesterolemia, chronic obstructive pulmonary disease, IMV at high positive end-expiratory pressure, low $\mathrm{PaO}_{2} / \mathrm{FiO}_{2}$ on ICU admission, high SOFA score, acute kidney injury, reduced respiratory system compliance, late pulmonary infections, and cardiovascular complications [14, 19].

In our setting, intra-hospital mortality rate was $31 \%$, in line with previous reports [18]. Risk factors for intrahospital mortality identified in our cohort confirmed all previously reported predictors [10-13]. Furthermore, increased C-reactive protein and lactate dehydrogenase and reduced lymphocyte count were all associated with increased mortality in our study population, which is in good agreement with previous data showing a positive association between severity/mortality rate of COVID-19 illness and biomarkers such as C-reactive protein, lactate dehydrogenase, and lymphopenia $[12,13]$. Of note, the intubation rate in our study was $35.4 \%$, which is consistent with the IMV incidence range among COVID-19 patients (12-33.1\%) [20-22].

Older age, BMI, comorbidities-i.e., hypertension, diabetes, and cardiovascular diseases-, shortness of breath, $\mathrm{SpO}_{2}<90 \%$, and increased respiratory rate are well- known predictors of intubation in patients admitted for COVID-19 [9]. In our cohort of patients, we confirm that reduced $\mathrm{SpO}_{2}$ and/or $\mathrm{PaO}_{2} / \mathrm{FiO}_{2}$ are risk factors for IMV. We also show that increased $\mathrm{C}$-reactive protein and lactate dehydrogenase serum concentrations and elevated total white blood cell count are predictors of intubation, which is in good agreement with previous reports demonstrating the association between the aforementioned biomarkers and illness severity $[12,13]$.

Lung aeration loss on chest CT scan has been previously shown to be an independent predictor of death and ICU admission in COVID-19 patients suffering from hypoxemic ARF [17, 23]. Fittingly, we found that reduced aerated lung volume and increased GGO and/or consolidation and fibrosis are indicators of poor outcome and intubation. In this regard, Colombi et al. [23] have previously demonstrated an association between mortality and exudative consolidation, which may be suggestive of concomitant bacterial infection associated with death in COVID-19 patients [24].

To date, several models have been proposed to estimate the risk of COVID-19 patients to be hospitalized or to experience a poor outcome from the infection in order to assist medical staff in triaging patients when allocating limited healthcare resources [25]. With particular regard to predictive models for mortality and progression to a more severe or critical condition, the most frequently used predictors include comorbidities, age, sex, lymphocyte count, C-reactive protein, body temperature, creatinine, and imaging features [25]. The discrimination of these models ranged from 0.68 to 0.98 for intra-hospital mortality [26] and from 0.73 to 0.99 for worsening to a more critical state [27].

Here, we propose two novel RF models developed by including all the demographic, clinical, hematochemical, and radiological variables from our cohort of COVID-19 patients having less than $10 \%$ of missing data. The predictive balanced accuracy was high for both RF models, probably because the number of nodes exceeding an importance of 50 was very high for each algorithm. Among the items included in our RF algorithms for prediction of mortality and intra-hospital intubation, blood glucose and the symptom onset duration were the two factors that, in addition to the predictors listed above, showed an importance $>50$.

Our findings are in keeping with recent results suggesting that hyperglycemia, even in the absence of frank diabetes, is associated with a negative outcome compared to normoglycemic individuals as well as to those with pre-existing diabetes and COVID-19 [28]. Also, the symptom onset duration was confirmed to be a poor outcome predictor, being a fever lasting more than 7 days from onset of illness associated with increased ICU admission [29]. 
Table 2 Patient characteristics and clinical, laboratory, and CT findings relative to intubated and non-intubated patients

\begin{tabular}{|c|c|c|c|c|c|c|c|}
\hline Variable & $\begin{array}{l}\text { All } \\
\text { patients } \\
(n=158)\end{array}$ & $\begin{array}{l}\text { Non-intubated } \\
n=102\end{array}$ & $\begin{array}{l}\text { Intubated } \\
n=56\end{array}$ & $\begin{array}{l}\text { Total } \\
(158)\end{array}$ & OR (univariable) & $\begin{array}{l}\text { Cut } \\
\text { point }\end{array}$ & AUC \\
\hline Age (year) & 158 & $63(55-71)$ & $62(56-68)$ & $62(55-70)$ & $0.90(0.59-1.37, p=0.619$ & 64 & 0.53 \\
\hline \multicolumn{8}{|l|}{ Sex } \\
\hline Male & & $72(71)$ & $46(82)$ & $118(75)$ & & - & - \\
\hline Female & & $30(29)$ & $10(18)$ & $40(25)$ & $0.52(0.22-1.14, p=0.113)$ & - & - \\
\hline $\mathrm{PaO}_{2} / \mathrm{FIO}_{2}$ & 154 & $280(246-314)$ & $223(168-278)^{*}$ & $264(21-312)$ & $0.43(0.26-0.68, p<0.001)$ & 245 & 0.68 \\
\hline $\mathrm{SpO}_{2}(\%)$ & 156 & $93(90-95)$ & $88(79-97)^{*}$ & 92 (88-96) & $0.55(0.39-0.75, p<0.001)$ & 88.4 & 0.66 \\
\hline Symptom onset & 151 & $7(5-10)$ & $7(5-10)$ & $7(5-10)$ & $0.92(0.56-1.49, p=0.733)$ & 1 & 0.51 \\
\hline Body mass index $\left(\mathrm{kg} / \mathrm{m}^{2}\right)$ & 107 & $27.3(24-31)$ & $27.7(25-31)$ & $27.5(24-31)$ & $0.96(0.64-1.45, p=0.859)$ & 27.6 & 0.53 \\
\hline \multicolumn{8}{|l|}{ Comorbidity } \\
\hline Hypertension & 158 & $53(52.0 \%)$ & $25(45 \%)$ & 78 (49\%) & $0.75(0.39-1.43, p=0.379)$ & - & - \\
\hline Coronary artery disease & 158 & $11(11 \%)$ & $6(11 \%)$ & $17(11 \%)$ & $1.00(0.34-2.66, p=0.996)$ & - & - \\
\hline Other cardiovascular disease & 158 & $6(6 \%)$ & $3(5 \%)$ & $9(6 \%)$ & $0.91(0.19-3.58, p=0.892)$ & - & - \\
\hline Neurologic disease & 158 & $3(3 \%)$ & $5(9 \%)$ & $8(5 \%)$ & $\begin{array}{l}3.24(0.76-16.28, p= \\
0.118)\end{array}$ & - & - \\
\hline Diabetes & 158 & $23(23 \%)$ & $11(20 \%)$ & $34(22 \%)$ & $0.84(0.36-1.85, p=0.671)$ & - & - \\
\hline Chronic kidney failure & 158 & $6(6 \%)$ & $2(4 \%)$ & $8(5 \%)$ & $0.59(0.08-2.67, p=0.530)$ & - & - \\
\hline Oncologic & 158 & $8(8 \%)$ & $6(11 \%)$ & $14(9 \%)$ & $1.41(0.44-4.28, p=0.545)$ & - & - \\
\hline Dyslipidemia & 158 & $16(16 \%)$ & $7(13 \%)$ & $23(15 \%)$ & $0.77(0.28-1.93, p=0.588)$ & - & - \\
\hline COPD & 158 & $5(5 \%)$ & $0(0.0)$ & $5(3 \%)$ & Not estimable & - & - \\
\hline Asthma & 158 & $4(4 \%)$ & $0(0.0)$ & $4(4 \%)$ & Not estimable & - & - \\
\hline Autoimmune disease & 158 & $7(7 \%)$ & $5(9 \%)$ & $12(8 \%)$ & $1.33(0.38-4.38, p=0.640)$ & - & - \\
\hline Mental illness & 158 & $4(4 \%)$ & $2(4 \%)$ & $6(4 \%)$ & $0.91(0.12-4.81, p=0.912)$ & - & - \\
\hline Smoking history & 158 & & & & & & \\
\hline Never & & $95(93 \%)$ & $51(91 \%)$ & $146(92 \%)$ & - & - & - \\
\hline Current or former & & $7(7 \%)$ & $5(9 \%)$ & $12(8 \%)$ & $1.33(0.38-4.38, p=0.640)$ & - & - \\
\hline \multicolumn{8}{|l|}{$C T$ findings } \\
\hline Well-aerated parenchyma & 158 & $74(64-84)$ & $63(52-74)^{*}$ & $68(58-79)$ & $0.37(0.22-0.58, p<0.001)$ & 67.7 & 0.7 \\
\hline Ground glass opacity & 158 & $23(14-32)$ & $33(24-42)^{*}$ & $25(16-35)$ & $2.50(1.52-4.26, p<0.001)$ & 28.4 & 0.67 \\
\hline $\begin{array}{l}\text { Other: consolidation and } \\
\text { fibrosis }\end{array}$ & 158 & $3(0.7-5)$ & $7(2.2-11)^{*}$ & $3(0.3-7)$ & $2.13(1.46-3.26, p<0.001)$ & 5.8 & 0.68 \\
\hline \multicolumn{8}{|l|}{ Laboratory findings } \\
\hline White blood count, $\times 10^{3} / \mu \mathrm{L}$ & 158 & $5.9(4.3-7.4)$ & $6.6(4-9)^{*}$ & $6.1(4.1-8.1)$ & $1.50(1.06-2.18, p=0.026)$ & 7.03 & 0.58 \\
\hline Lymphocyte count, $\times 10^{3} / \mathrm{\mu L}$ & 158 & $1.1(0.8-1.4)$ & $0.9(0.7-1.2)^{*}$ & $1(0.7-1.3)$ & $0.56(0.33-0.90, p=0.024)$ & 1.06 & 0.61 \\
\hline C-reactive protein, $\mathrm{mg} / \mathrm{dL}$ & 158 & $7(3-12)$ & $12(5-19)^{*}$ & $8(2-14)$ & $3.37(1.92-6.22, p<0.001)$ & 11.3 & 0.68 \\
\hline Lactate dehydrogenase, U/L & 158 & $694(494-894)$ & $870(641-1091)^{*}$ & $766(560-972)$ & $2.20(1.39-3.67, p=0.001)$ & 796 & 0.69 \\
\hline Glycemia, mg/dL & 158 & $113(91-134)$ & $133(113-152)$ & $121(99-142)$ & $1.11(0.88-1.42, p=0.373)$ & 128 & 0.61 \\
\hline Fibrinogen, mg/dL & 63 & $583(520-646)$ & $577(490-664)$ & $581(506-656)$ & $0.91(0.59-1.39, p=0.667)$ & 538 & 0.58 \\
\hline Ferritin, ng/mL & 48 & $\begin{array}{l}1082(641- \\
1523)\end{array}$ & $\begin{array}{l}1330(563- \\
2096)\end{array}$ & $\begin{array}{l}1111.5(629- \\
1594)\end{array}$ & $1.63(0.92-3.03, p=0.098)$ & 1514 & 0.61 \\
\hline Procalcitonin & 103 & $0.1(0.05--0.2)$ & $0.2(0.05-0.4)$ & $0.1(0-0.2)$ & $1.04(1.00-1.13, p=0.154)$ & 0.14 & 0.73 \\
\hline Troponin ng/L & 93 & $11(4-18)$ & $12(1-23)$ & $11(3-20)$ & $0.99(0.92-1.03, p=0.751)$ & 17 & 0.58 \\
\hline
\end{tabular}

Descriptive statistics were reported as median and interquartile range for continuous variables and percentages (absolute numbers) for categorical variables. The logistic regression model, odds ratio (OR) together with the $95 \%$ confidence intervals $(95 \% \mathrm{Cl})$, and $p$ values are shown for each predictor considered. Asterisks show statistical significance variables. The cut point maximizing the sum of sensitivity and specificity is shown for the continuous variable together with the corresponding area under the curve (AUC) 


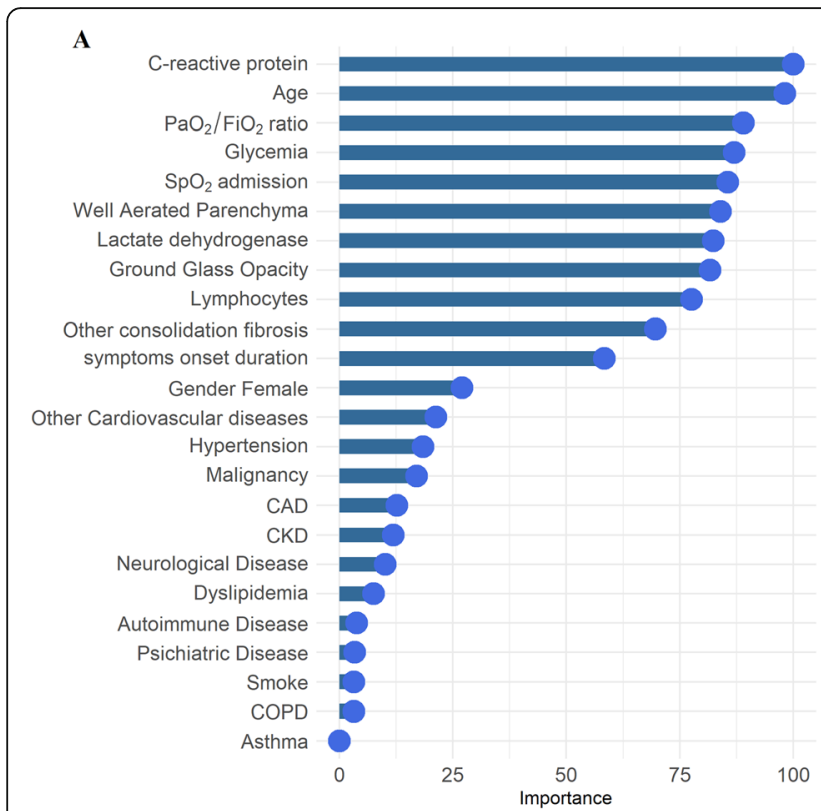

B

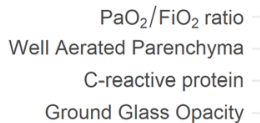

Other consolidation fibrosis

Glycemia

Lactate dehydrogenase

Lymphocytes

Age

symptoms onset duration

Gender Female

Hypertension

Diabetes

Neurological Disease

CAD

Malignancy

Smoke

Dyslipidemia

Other Cardiovascular diseases

Autoimmune Disease

Psichiatric Disease

CKD

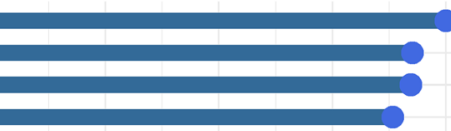

Fig. 2 Important predictor variables (importance > 50) in the random forest (RF) models for intra-hospital mortality (a) and intubation

prediction (b)

Although our study confirms with an innovative approach (i.e., RF) the risk factors of intubation and mortality found in the recent literature, it has several limitations. First, due the retrospective nature of the present singlecenter study, our results lack of generalizability. Second, no power sample was estimated for RF model accuracy assessment. Thus, no definitive conclusions can be drawn on the precision of our algorithm for intubation and intra- hospital mortality prediction. Third, some variables were excluded during the algorithm construction due to missing data occurrence $>10 \%$ and the fact that other laboratory values, such as $\mathrm{PaCO}_{2}$, creatinine, and D-Dimer were not collected. Lastly, our prediction models were not validated before the present investigation. Therefore, a future prospective investigation addressing the validation of our models is clearly needed.
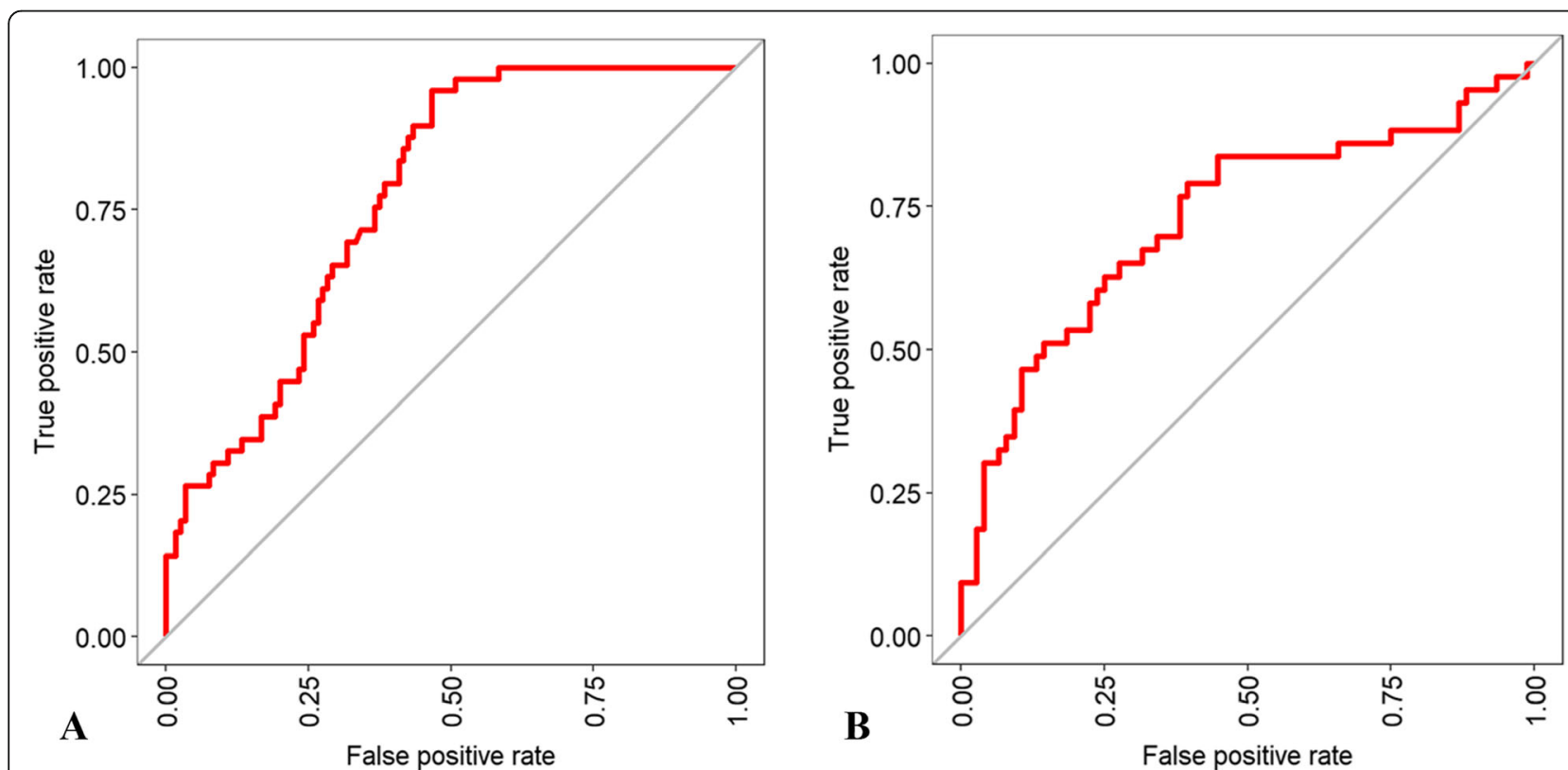

Fig. 3 AUC of the RF models. a) The RF model balanced accuracy in predicting intra-hospital mortality is $0.89(\kappa=0.72 ; A U C=0.73)$. $\mathbf{b}$ The RF model balanced accuracy in predicting intubation is $0.9(K=0.75$; AUC $=0.74)$ 


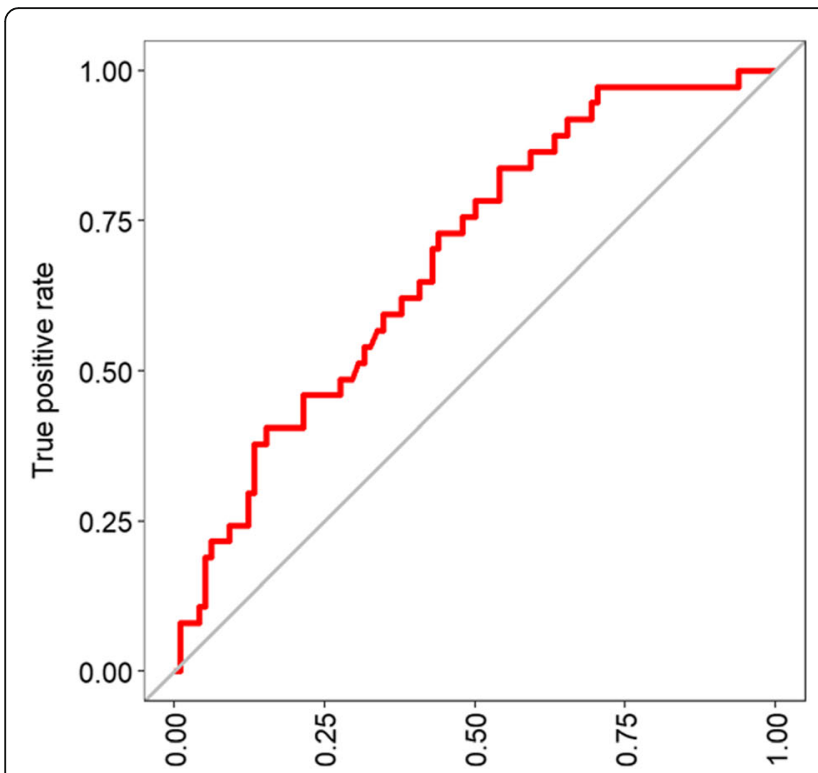

A False positive rate

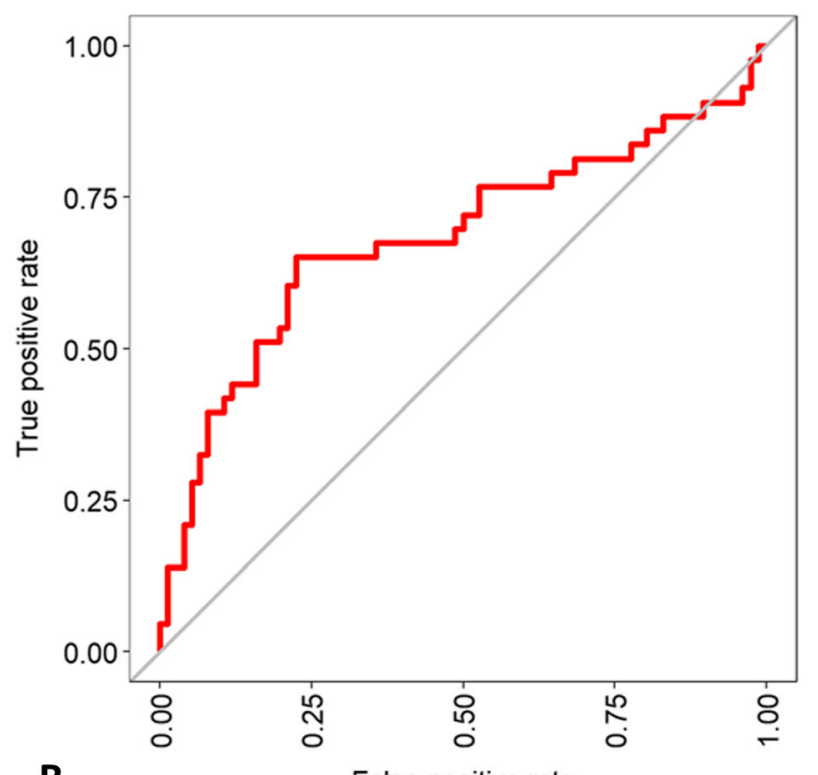

B

False positive rate

Fig. 4 RF model performance without CT parameters. a The RF model balanced accuracy in predicting intra-hospital mortality is $0.75(K=0.1)$. $\mathbf{b}$ The RF model balanced accuracy in predicting intubation is $0.69(k=0.29)$

\section{Conclusions}

In our cohort of COVID-19 patients, we confirmed all demographic, clinical, hemato-chemical, and radiologic predictors of adverse outcomes previously reported. In addition, our innovative RF models based on the risk factors identified in our subset showed a good level of accuracy in predicting intra-hospital mortality and intubation. Thus, this approach may help to accurately identify patients at higher risk of deterioration, which would be particularly important in case of disproportion between resources and demand. Our results await further confirmation in larger multicentric prospective studies.

\section{Abbreviations}

ARF: Acute respiratory failure; BMI: Body mass index; BiPAP: Bilevel positive airway pressure; CAD: Coronary artery disease; COPD: Chronic obstructive pulmonary disease; CPAP: Continuous positive airway pressure; COVID-19: Coronavirus disease 19; CT: Computerized tomography; DICOM: Digital Imaging and Communications in Medicine; DT: Decision trees; GGO: Ground glass opacity; HU: Hounsfield; ICU: Intensive care unit; IMV: Invasive mechanical ventilation; PACS: Picture Archiving and Communication System; $\mathrm{PaO}_{2} / \mathrm{FiO}_{2}$ : Arterial oxygen pressure on inspired oxygen fraction ratio; RF: Random forest; RT-PCR: Real-time reverse transcriptase-polymerase chain reaction; SARS-CoV-2: Severe acute respiratory syndrome coronavirus 2; SOFA: Sequential organ failure assessment;

$\mathrm{SpO}_{2}$ : Peripheral oxygen saturation

\section{Supplementary Information}

The online version contains supplementary material available at https://doi. org/10.1186/s44158-021-00016-5.

Additional file 1. Supplementary information

\section{Acknowledgements}

We thank Dr. Arsura for the language revision of the manuscript.

\section{Human and animal rights}

The study was conducted on human subjects; ethical standards were followed.

\section{Informed consent}

Informed consent was not applicable since this is a retrospective study.

\section{Authors' contributions}

TC, GC, and RV had the idea for and designed the study, had full access to all of the data in the study, contributed to the design of the study and to the interpretation of data for the work, and drafted the paper. DA contributed to formal analysis and interpretation data and drafted the paper. $M B, S B, D N, D Z$, and $L C$ contributed to the acquisition, integrity, and analysis of the data. AC and FDC contributed to manuscript revision, read, and approved the submitted version. All authors (1) agreed to be accountable for all aspects of the work in ensuring that questions related to the accuracy or integrity of any part of the work are appropriately investigated and resolved, (2) revised the work critically for important intellectual content, and (3) gave final approval of the version to be published.

Funding

No funding received.

\section{Declarations}

\section{Ethics approval and consent to participate}

The research was in accordance with the 1964 Helsinki Declaration and ethical approval received from Comitato Etico Interaziendale.

\section{Consent for publication}

All authors consent for publication.

\section{Competing interests}

The authors declare that they have no conflicts of interest.

\section{Author details}

${ }^{1}$ Anestesia e Terapia Intensiva, Azienda Ospedaliero Universitaria "Maggiore della Carità", Novara, Italy. ${ }^{2}$ Dipartimento di Medicina Traslazionale, Università del Piemonte Orientale, Novara, Italy. ${ }^{3}$ Radiologia, Azienda Ospedaliero Universitaria "Maggiore della Carità", Novara, Italy. "Medicina d'Urgenza, Azienda Ospedaliero Universitaria "Maggiore della Carità", Novara, Italy. 
Received: 31 August 2021 Accepted: 27 October 2021 Published online: 27 November 2021

\section{References}

1. Vincent JL, Creteur J (2020) Ethical aspects of the COVID-19 crisis: how to deal with an overwhelming shortage of acute beds. Eur Heart J Acute Cardiovasc Care 3(9):248-252. https://doi.org/10.1177/2048872620922788

2. Ewig S, Ruiz M, Mensa J, Marcos MA, Martinez JA, Arancibia F, Niederman MS, Torres A (1998) Severe community-acquired pneumonia. Assessment of severity criteria. Am J Respir Crit Care Med 4(158):1102-1108. https://doi. org/10.1164/ajrccm.158.4.9803114

3. Phua J, Ngerng WJ, Lim TK (2010) The impact of a delay in intensive care unit admission for community-acquired pneumonia. Eur Respir J 4(36):826833. https://doi.org/10.1183/09031936.00154209

4. Renaud B, Brun-Buisson C, Santin A, Coma E, Noyez C, Fine MJ, Yealy DM, Labarere J (2012) Outcomes of early, late, and no admission to the intensive care unit for patients hospitalized with community-acquired pneumonia. Acad Emerg Med 3(19):294-303. https://doi.org/10.1111/j.1553-2712.2012. 01301.x

5. Demoule A, Girou E, Richard JC, Taille S, Brochard L (2006) Benefits and risks of success or failure of noninvasive ventilation. Intensive Care Med 11(32): 1756-1765. https://doi.org/10.1007/s00134-006-0324-1

6. Demoule A, Chevret S, Carlucci A, Kouatchet A, Jaber S, Meziani F, Schmidt M, Schnell D, Clergue C, Aboab J, Rabbat A, Eon B, Guerin C, Georges H, Zuber B, Dellamonica J, Das V, Cousson J, Perez D, Brochard L, Azoulay E (2016) Changing use of noninvasive ventilation in critically ill patients: trends over 15 years in francophone countries. Intensive Care Med 1(42):8292. https://doi.org/10.1007/s00134-015-4087-4

7. Aziz S, Arabi YM, Alhazzani W, Evans L, Citerio G, Fischkoff K, Salluh J, Meyfroidt G, Alshamsi F, Oczkowski S, Azoulay E, Price A, Burry L, Dzierba A, Benintende A, Morgan J, Grasselli G, Rhodes A, Moller MH, Chu L, Schwedhelm S, Lowe JJ, Bin D, Christian MD (2020) Managing ICU surge during the COVID-19 crisis: rapid guidelines. Intensive Care Med 7(46):13031325. https://doi.org/10.1007/s00134-020-06092-5

8. De Vita N, Scotti L, Cammarota G, Racca F, Pissaia C, Maestrone C, Colombo D, Olivieri C, Della CF, Barone-Adesi F, Navalesi P, Vaschetto R (2021) Predictors of intubation in COVID-19 patients treated with out-of-ICU continuous positive airway pressure. Pulmonology. S2531-0437(21):0000200007. https://doi.org/10.1016/j.pulmoe.2020.12.010

9. Hur K, Price CPE, Gray EL, Gulati RK, Maksimoski M, Racette SD, Schneider AL, Khanwalkar AR (2020) Factors Associated with intubation and prolonged intubation in hospitalized patients with COVID-19. Otolaryngol Head Neck Surg 1(163):170-178. https://doi.org/10.1177/0194599820929640

10. Huang Y, Lyu X, Li D, Wang L, Wang Y, Zou W, Wei Y, Wu X (2020) A cohort study of 676 patients indicates D-dimer is a critical risk factor for the mortality of COVID-19. PLoS One 11(15):e0242045. https://doi.org/10.1371/ journal.pone.0242045

11. Guan WJ, Ni ZY, Hu Y, Liang WH, Ou CQ, He JX, Liu L, Shan H, Lei CL, Hui DSC, Du B, Li L, Zeng G, Yuen KY, Chen RC, Tang CL, Wang T, Chen PY, Xiang J, Li SY, Wang JL, Liang ZJ, Peng YX, Wei L, Liu Y, Hu YH, Peng P, Wang JM, Liu JY, Chen Z, Li G, Zheng ZJ, Qiu SQ, Luo J, Ye CJ, Zhu SY, Zhong NS (2020) Clinical characteristics of coronavirus disease 2019 in China. N Engl J Med 18(382):1708-1720. https://doi.org/10.1056/NEJMoa2 002032

12. Henry BM, de Oliveira MHS, Benoit S, Plebani M, Lippi G (2020) Hematologic, biochemical and immune biomarker abnormalities associated with severe illness and mortality in coronavirus disease 2019 (COVID-19): a metaanalysis. Clin Chem Lab Med 7(58):1021-1028. https://doi.org/10.1515/ cclm-2020-0369

13. Malik P, Patel U, Mehta D, Patel N, Kelkar R, Akrmah M, Gabrilove JL, Sacks H (2021) Biomarkers and outcomes of COVID-19 hospitalisations: systematic review and meta-analysis. BMJ Evid Based Med 3(26):107-108. https://doi. org/10.1136/bmjebm-2020-111536

14. Gamberini L, Tonetti T, Spadaro S, Zani G, Mazzoli CA, Capozzi C, Giampalma E, Bacchi Reggiani ML, Bertellini E, Castelli A, Cavalli I, Colombo D, Crimaldi F, Damiani F, Fogagnolo A, Fusari M, Gamberini E, Gordini G, Laici C, Lanza MC, Leo M, Marudi A, Nardi G, Ottaviani I, Papa R, Potalivo A, Russo E, Taddei S, Volta CA, Ranieri VM (2020) Factors influencing liberation from mechanical ventilation in coronavirus disease 2019: multicenter observational study in fifteen Italian ICUs. J Intensive Care 8:80. https://doi. org/10.1186/s40560-020-00499-4
15. Li K, Fang Y, Li W, Pan C, Qin P, Zhong Y, Liu X, Huang M, Liao Y, Li S (2020) $\mathrm{CT}$ image visual quantitative evaluation and clinical classification of coronavirus disease (COVID-19). Eur Radiol 8(30):4407-4416. https://doi.org/1 0.1007/s00330-020-06817-6

16. Rubin GD, Ryerson CJ, Haramati LB, Sverzellati N, Kanne JP, Raoof S, Schluger NW, Volpi A, Yim JJ, Martin IBK, Anderson DJ, Kong C, Altes T, Bush A, Desai SR, Goldin J, Goo JM, Humbert M, Inoue Y, Kauczor HU, Luo F, Mazzone PJ, Prokop M, Remy-Jardin M, Richeldi L, Schaefer-Prokop CM, Tomiyama N, Wells AU, Leung AN (2020) The role of chest imaging in patient management during the COVID-19 pandemic: a multinational consensus statement from the Fleischner Society. Chest 1(158):106-116. https://doi.org/10.1148/radiol.2020201365

17. Lanza E, Muglia R, Bolengo I, Santonocito OG, Lisi C, Angelotti G, Morandini P, Savevski V, Politi LS, Balzarini L (2020) Quantitative chest CT analysis in COVID-19 to predict the need for oxygenation support and intubation. Eur Radiol 12(30):6770-6778. https://doi.org/10.1007/s00330-020-07013-2

18. Vaschetto R, Barone-Adesi F, Racca F, Pissaia C, Maestrone C, Colombo D, Olivieri C, De VN, Santangelo E, Scotti L, Castello L, Cena T, Taverna M, Grillenzoni L, Moschella MA, Airoldi G, Borre S, Mojoli F, Della CF, Baggiani M, Baino S, Balbo P, Bazzano S, Bonato V, Carbonati S, Crimaldi F, Daffara V, De CL, Maestrone M, Malerba M, Moroni F, Perucca R, Pirisi M, Rondi V, Rosalba D, Vanni L, Vigone F, Navalesi P, Cammarota G (2021) Outcomes of COVID-19 patients treated with continuous positive airway pressure outside the intensive care unit. ERJ Open Res 1(7):00541-02020. https://doi.org/1 $0.1183 / 23120541.00541-2020$

19. Grasselli G, Greco M, Zanella A, Albano G, Antonelli M, Bellani G, Bonanomi E, Cabrini L, Carlesso E, Castelli G, Cattaneo S, Cereda D, Colombo S, Coluccello A, Crescini G, Forastieri MA, Foti G, Fumagalli R, lotti GA, Langer T, Latronico N, Lorini FL, Mojoli F, Natalini G, Pessina CM, Ranieri VM, Rech R, Scudeller L, Rosano A, Storti E, Thompson BT, Tirani M, Villani PG, Pesenti A, Cecconi M (2020) Risk factors associated with mortality among patients with COVID-19 in intensive care units in Lombardy. Italy. JAMA Intern Med 10(180):1345-1355. https://doi.org/10.1001/jamainternmed.2020.3539

20. Goyal P, Choi JJ, Pinheiro LC, Schenck EJ, Chen R, Jabri A, Satlin MJ, Campion TR Jr, Nahid M, Ringel JB, Hoffman KL, Alshak MN, Li HA Wehmeyer GT, Rajan M, Reshetnyak E, Hupert N, Horn EM, Martinez FJ, Gulick RM, Safford MM (2020) Clinical characteristics of COVID-19 in New York City. N Engl J Med 24(382):2372-2374. https://doi.org/10.1056/NEJMc2 010419

21. Richardson S, Hirsch JS, Narasimhan M, Crawford JM, McGinn T, Davidson KW, Barnaby DP, Becker LB, Chelico JD, Cohen SL, Cookingham J, Coppa K, Diefenbach MA, Dominello AJ, Duer-Hefele J, Falzon L, Gitlin J, Hajizadeh N, Harvin TG, Hirschwerk DA, Kim EJ, Kozel ZM, Marrast LM, Mogavero JN, Osorio GA, Qiu M, Zanos TP (2020) Presenting characteristics, comorbidities, and outcomes among 5700 patients hospitalized with COVID-19 in the New York City Area. JAMA 20(323):2052-2059. https://doi.org/10.1001/jama.2020. 6775

22. Wang D, Hu B, Hu C, Zhu F, Liu X, Zhang J, Wang B, Xiang H, Cheng Z, Xiong Y, Zhao Y, Li Y, Wang X, Peng Z (2020) Clinical characteristics of 138 hospitalized patients with 2019 novel coronavirus-infected pneumonia in Wuhan. China. JAMA 11(323):1061-1069. https://doi.org/10.1001/jama.2020.1585

23. Colombi D, Villani GD, Maffi G, Risoli C, Bodini FC, Petrini M, Morelli N, Anselmi P, Milanese G, Silva M, Sverzellati N, Michieletti E (2020) Qualitative and quantitative chest $C T$ parameters as predictors of specific mortality in COVID-19 patients. Emerg Radiol 6(27):701-710. https://doi.org/10.1007/s1 0140-020-01867-1

24. Mirzaei R, Goodarzi P, Asadi M, Soltani A, Aljanabi HAA, Jeda AS, Dashtbin S, Jalalifar S, Mohammadzadeh R, Teimoori A, Tari K, Salari M, Ghiasvand S, Kazemi S, Yousefimashouf R, Keyvani H, Karampoor S (2020) Bacterial coinfections with SARS-CoV-2. IUBMB Life 10(72):2097-2111. https://doi.org/1 $0.1002 / i u b .2356$

25. Wynants L, Van CB, Collins GS, Riley RD, Heinze G, Schuit E, Bonten MMJ, Dahly DL, Damen JAA, Debray TPA, de Jong VMT, De VM, Dhiman P, Haller MC, Harhay MO, Henckaerts L, Heus P, Kammer M, Kreuzberger N, Lohmann A, Luijken K, Ma J, Martin GP, McLernon DJ, Andaur Navarro CL, Reitsma JB, Sergeant JC, Shi C, Skoetz N, Smits LJM, Snell KIE, Sperrin M, Spijker R, Steyerberg EW, Takada T, Tzoulaki I, van Kuijk SMJ, van BB, van der Horst ICC, van Royen FS, Verbakel JY, Wallisch C, Wilkinson J, Wolff R, Hooft L, KGM M, van SM (2020) Prediction models for diagnosis and prognosis of covid-19: systematic review and critical appraisal. BMJ 369:m1328. https:// doi.org/10.1136/bmj.m1328 
26. Xie J, Hungerford D, Chen H, Abrams ST, Wang G, Wang Y, Kang H, Bonnett L, Zheng R, Li X, Tong Z, Du B, Qiu H, Toh C-H (2020) Development and external validation of a prognostic multivariable model on admission for hospitalized patients with COVID-19. https://doi.org/10.1101/2020.03.28.2004 5997

27. Diaz-Quijano FA, da Silva JMN, Ganem F, Oliveira S, Vesga-Varela AL, Croda J (2020) A model to predict SARS-CoV-2 infection based on the first threemonth surveillance data in Brazil. Trop Med Int Health 11(25):1385-1394. https://doi.org/10.1111/tmi.13476

28. Singh AK, Singh R (2020) Hyperglycemia without diabetes and new-onset diabetes are both associated with poorer outcomes in COVID-19. Diabetes Res Clin Pract 167:108382. https://doi.org/10.1016/j.diabres.2020.108382

29. Ng DHL, Choy CY, Chan YH, Young BE, Fong SW, Ng LFP, Renia L, Lye DC, Chia PY (2020) Fever patterns, cytokine profiles, and outcomes in COVID-19. Open Forum. Infect Dis 9(7):ofaa375. https://doi.org/10.1093/ofid/ofaa375

\section{Publisher's Note}

Springer Nature remains neutral with regard to jurisdictional claims in published maps and institutional affiliations.

Ready to submit your research? Choose BMC and benefit from:

- fast, convenient online submission

- thorough peer review by experienced researchers in your field

- rapid publication on acceptance

- support for research data, including large and complex data types

- gold Open Access which fosters wider collaboration and increased citations

- maximum visibility for your research: over $100 \mathrm{M}$ website views per year

At $\mathrm{BMC}$, research is always in progress.

Learn more biomedcentral.com/submissions 